\title{
Mãe paralítica no teatro das oligarquias? \\ O papel da Bahia na Primeira República para além do café-com-leite*
}

\section{Disabled mother at the oligarchies' theatre?}

\section{The role of Bahia in the First Republic beyond caffé-latte politics}

\author{
Antonio LUIGI NEGRO** \\ Departamento de História \\ Universidade Federal da Bahia \\ Salvador (BA) \\ Brasil \\ JONAS BRITO*** \\ Departamento de História \\ Universidade Federal da Bahia \\ Salvador (BA) \\ Brasil
}

RESUMO Apesar de ter cabido à Bahia a segunda maior bancada do congresso republicano (menor apenas que a mineira, igual à dos paulistas; maior, portanto, que a dos gaúchos), a relevância de seu papel na Primeira República é comparada com sua situação privilegiada no império ou, além disto, é confrontada com o excepcionalismo dos paulistas: fazendeiros capitalistas, burgueses e industriais. A Bahia foi contudo um estado que, monarquista até a medula da escravatura, influiu os governos republicanos. Em 1908, na Exposição Nacional, suas elites conseguiram representar este papel com desenvoltura e eficácia.

* Artigo recebido em: 21/06/2012. Aprovado em: 21/12/2012.

**Pesquisador CNPq. Contato: negro@ufba.br.

*** Mestrando em História pela Universidade Federal da Bahia, Bolsista Capes. Contato: brito.jonas@outlook.com 
Palavras-chave Exposição Nacional de 1908, Brasil, Primeira República, Bahia

ABSTRACT Despite the fact that Bahia took the second largest number of chairs in the Brazilian congress, the relevance of its role is constantly reduced when compared with its Imperial past or with Paulistas' exceptionalism (capitalist landowners, industrial bourgeoisie). Bahia was nonetheless a state that, despite its Monarchism, influenced the new Republican régime. In 1908, at the National Exposition in Rio de Janeiro, Bahian elites managed to perform very well in this sense.

Keywords National Exposition of 1908, Brazil, First Republic, Bahia

Em 1924, a posse de Góis Calmon no governo da Bahia marcou a entrada do estado na fase derradeira de sua história política durante a Primeira República. Principiava, por um lado, o declínio do ex-governador J. J. Seabra e seu grupo político (os seabristas). Por outro lado, ascendiam grupos organizados, como de hábito, em facções. Seabra fora alvo do plano do presidente mineiro Artur Bernardes de, em associação com oposições locais, destituir do poder as situações nos estados membros da Reação Republicana. ${ }^{1}$ A oposição a Seabra era constituída basicamente por dois grupos em redor de Rui Barbosa e Aurelino Leal. Alguns membros seus eram homens experientes, que já haviam ocupado cargos nas administrações estadual e federal, destacando-se Miguel e Antônio Calmon (irmãos de Góis Calmon), os irmãos Otávio e João Mangabeira, além de Simões Filho, Pedro Lago e Geraldo Rocha. ${ }^{2}$

Por doze anos, os seabristas ocuparam o poder. Foram dois mandatos do seu chefe (1912-1916 e 1920-1924) e um de Antônio Moniz (1916-1920), baiano quatrocentão e segundo homem do Partido Democrata. Embora as ações de Seabra, visando inserir-se na política baiana e brasileira, tenham começado no final da monarquia, o resultado de suas tentativas apareceu só depois de 1889. Cortejando a situação dos primeiros governos republicanos, granjeou o Ministério da Justiça (1902-1906) de Rodrigues Alves e ameaçou o complicado equilíbrio de poder entre Rui Barbosa e os mandachuvas do Partido Republicano da Bahia (PRB). Após acumular forças - inclusive assumindo o Ministério da Viação e Obras Públicas em 1910 no

\footnotetext{
1 A Reação Republicana era um somatório entre Rio de Janeiro, Rio Grande do Sul, Bahia e Pernambuco em torno da chapa dissidente à Presidência, de Nilo Peçanha e Seabra em 1921. Ver: FERREIRA, Marieta de M. A reação republicana e a crise do pacto oligárquico. Estudos Históricos, Rio de Janeiro, n.11, v.6, p.9-23, 1993.

2 SAMPAIO, Consuelo Novais. Partidos políticos na Bahia da Primeira República. Salvador: Edufba, 1998, p.143 e ss.
} 
governo Hermes da Fonseca-, Seabra apropriou-se do salvacionismo militar do general presidente e ameaçou Rui, sem no entanto sobrepujá-lo. ${ }^{3}$ No governo, Seabra estabeleceu seu domínio na Bahia que, embora instável, atingiu o ápice em 1915 (após controlar a Assembléia Legislativa, e impor reformas na Constituição estadual e a lei de Reorganização Municipal). Em acréscimo, pegando empréstimos no exterior, promoveu um dos primeiros bota-abaixo da colonial cidade de Salvador, dizendo assim aformoseá-la. Como sucedeu de ocorrer com outros homens que ordenaram a derrubada do patrimônio histórico de uma cidade, a avenida J. J. Seabra - a famosa Baixa dos Sapateiros - hoje pouco tem das belezas que seu promotor mandou erguer no início do século XX. ${ }^{4}$

Com Góis Calmon no poder, a política baiana entrou numa significativa fase de domínio político de um só partido (no caso, o PRB). De modo geral, a Bahia era então conhecida como exemplo de estado politicamente dividido. Seus líderes dificilmente constituíam um controle efetivo, abrangente e durável sobre as frações existentes; e em todo o território estadual. Mesmo Seabra, que foi chefe durante 12 anos, lidou com renhida oposição. As diversas agremiações, fundadas e liquidadas ao longo dos anos, refletiam a tendência das elites políticas ao facciosismo, matriz de constantes defecções. Às vezes, porém, os conflitos ultrapassavam os limites dos partidos e envolviam atores distintos dos bacharéis do litoral e seus ancestrais (os senhores do açúcar do Recôncavo), como se deu com as reivindicações operárias no governo Antônio Moniz e com a Revolta Sertaneja. ${ }^{5}$

Efeito da turbulência entre as facções foi a fragilidade de representação concertada da Bahia nos espaços centrais de disputa política, decisão e captação de recursos, sitos na capital federal - a começar pela polarização entre Rui Barbosa e J. J. Seabra. No entanto, durante os governos de Góis Calmon (1924-1928) e Vital Soares (1928-1930), após o falecimento de Rui e tendo começado o declínio de Seabra, firmaram-se acordos que amenizaram as rivalidades no âmbito da estrutura partidária, contendo os conhecidos cismas, sobretudo com a reaparição do PRB em 1927. ${ }^{6}$ As greis que, a partir de então, conduziram a administração organizaram-se em três correntes: uma comandada pelos irmãos Calmon (Miguel, no Rio, Góis, governador, e Antônio, chefe político-eleitoral); a segunda por Otávio Mangabeira, que veio a ser ministro das Relações Exteriores de Washington

3 SARMENTO, Sílvia. A raposa e a águia. Salvador: Edufba, 2011, p.43-55. Seabra foi oposição apenas ao governo de Floriano Peixoto.

4 Sobre o "embelezamento" de Salvador, ver: LEITE, Rinaldo. E a Bahia civiliza-se. Salvador: Ufba, 1996 (História Dissertação de mestrado). Sobre os empréstimos tomados para as obras, ver: CUNHA, Joaci. O fazer político da Bahia na República Velha, 1906-1930. Salvador: Ufba, 2011 (História, Tese de doutorado).

5 Sobre a greve geral de 1919, ver: CASTELLUCCI, Aldrin. Industriais e operários baianos numa conjuntura de crise (1914-1921). Salvador: Fieb, 2004. Sobre os coronéis, ver: PANG, Eul-Soo. Coronelismo e oligarquias 1889-1934. Rio de Janeiro: Civilização Brasileira, 1979, p.134.

6 Esse era o segundo PRB. O primeiro foi criado em 1901 e extinto em 1911. 
Luís; e uma terceira formada por ex-seabristas organizados por Frederico Costa, presidente do senado estadual e nessa condição governador interino do estado por diversas vezes, inclusive em 1930.7

Rui, Seabra e Miguel Calmon possuíam endereço na capital Rio de Janeiro em 1908, quando da Exposição Nacional realizada na praia Vermelha. Sua presença em tal cenário é motivo para problematizarmos a personagem da Bahia como uma "mãe paralítica". É Emília Viotti da Costa quem faz menção à "divertida comédia" de Martim Francisco sobre a "'ruinosa'" associação entre São Paulo de um lado (abusado pelas províncias interesseiras) e o resto do Brasil de outro, no seu todo conivente com os "desfalques do Norte'". Entre desmaios e protestos acontecidos ante o anúncio de São Paulo de separar-se do resto sanguessuga, está em cena a Bahia, a "mãe paralítica", ao lado de Pernambuco, "leão sem juba". Distinta das muitas outras províncias, Minas Gerais é a "mulher séria e devota". São Paulo, claro, era o provedor de mãos endinheiradas, o "pagador geral do Império".

Em tom mais grave, Sérgio Buarque de Holanda vale-se de polarização similar entre São Paulo e o Norte. "É compreensível que a Abolição não tivesse afetado desastrosamente as regiões onde a cultura do café já preparara (...) o terreno para a aceitação de um regime de trabalho remunerado", escreve em Raízes do Brasil. "Nos estados do Norte", contrasta ele, "onde a baixa dos preços do açúcar no mercado mundial já tinha acarretado uma situação que o 13 de Maio veio apenas referendar, nada compensaria a catástrofe agrária". Emasculados, isto é, "tornados impotentes pelo golpe fatal da Abolição e por outros fatores", os velhos proprietários rurais "não tinham como intervir nas novas instituições". Resultado, a República "ignorou-os por completo". 9

Neste artigo, pretendemos apontar para a importância da presença dos baianos na Primeira República, não obstante suas divisões e percalços. São imagens assim - de paralisia e marginalidade - que interrogamos quando nos dirigimos para a presença da Bahia na Primeira República e, em particular, para a Exposição Nacional de 1908, quando o regime republicano não tinha nem 20 anos de história. Ao mesmo tempo, os baianos tinham algo a dizer sobre o centenário da abertura dos portos. Exibindo arte e eletricidade, economia, bem-estar e propaganda, o Brasil queria mostrar ao "mundo" (aos Estados Unidos e à Europa) que percorria uma via de avanços desde a Independência - a fazer cem anos em 1922. Acionados por seu orguIho provincial, diferentes estados enviaram para o Rio de Janeiro verbas,

7 PANG, Eul-Soo. Coronelismo e oligarquias 1889-1934, p.194. Sobre as relações entre Rui e Seabra, ver SARMENTO, Sílvia. A raposa e a águia.

8 FRANCISCO, Martim. São Paulo independente. Propaganda separatista. São Paulo: Tipografia União, 1887. A menção aos desfalques está em um discurso do autor, e não na comédia. Ver: COSTA, Emília Viotti da. Da monarquia à república: momentos decisivos. São Paulo: Editora Unesp, 2007, p.478.

9 HOLANDA, Sérgio Buarque de. Raízes do Brasil. São Paulo: Companhia das Letras, 1995, p.175 e 176. 
comissões, profissionais e produtos a fim de atestar o desenvolvimento e as potencialidades locais. Os mais importantes, dentro os quais a Bahia, construíram pavilhões para exibições próprias. A Bahia foi ainda beneficiada por ter sido um ministro baiano - Miguel Calmon - um dos produtores do cenário da exposição. Embora tivesse perdido para o Rio o status de capital e a família real lusa, essa desvantagem não arrasou suas elites. Parece-nos portanto que a Bahia não era nada figurativa no "teatro das oligarquias". ${ }^{10}$

Desdobrando a revisão de Viscardi referente ao café-com-leite - que reconsidera a facilidade, a estabilidade e a harmonia do suposto rodízio, sólido e amigável, entre São Paulo e Minas -, temos como conseqüência o reexame do papel da Bahia. Para nós, ao lado das reiteradas vicissitudes de ordem econômica (em particular da lavoura do açúcar e da involução industrial), os obstáculos decorrentes das brigas políticas facciosas acrescentaram impedimentos para suas elites, de um lado, atuarem com maior força no jogo federalista da Primeira República e, de outro, enfrentarem os desafios - nacionais e internacionais - tanto da lavoura açucareira quanto da indústria têxtil. Os prejuízos decorrentes das rivalidades entre os baianos não Ihes passavam despercebidos em seu próprio tempo e lugar. Em setembro de 1917, por exemplo, a "colônia baiana" no Rio de Janeiro (onde agiam as diferentes facções) homenageou a Força Pública da Bahia no Teatro Lírico, convidada à capital para as comemorações do Dia da Independência. ${ }^{11}$ Para a entrega da bandeira nacional aos soldados - ponto alto do evento - Rui Barbosa foi o escolhido. Este, ao mesmo tempo em que expressou uma visão otimista sobre as condições materiais do seu estado, apontou a política - ou melhor, a "politicagem" - como responsável pela preterição da Bahia no contexto nacional. Rui tinha lá a sua razão, pois, entre a eleição de Seabra em 1912 até 1922, a Bahia ficaria sem ministérios nos governos de Venceslau Brás, Delfim Moreira e Epitácio Pessoa (decerto um longo jejum). Ao senti-lo, o orador não poupou o grupo seabrista pela degradação

10 Utilizamos como fonte o livro da viajante: WRIGHT, Marie Robinson. The Brazilian National Exposition of 1908. Filadélfia: George Barrie \& Sons, 1908. A referência ao teatro das oligarquias propõe um roteiro em que diferentes atores ou personagens estão presentes: oligarquias de grandes, médios e pequenos estados; o Exército; o Estado nacional; o parlamento; setores urbanos médios; movimento operário; imprensa. Todos foram atuantes, embora suas posições fossem claramente hierarquizadas. O enredo passa pelas cambiantes relações de aliança e desconfiança, com cenas, muitas vezes íntimas, de convergência e afastamento, amizades e reservas. VISCARDI, Cláudia. O teatro das oligarquias. Belo Horizonte: Com Arte, 2001, p.360.

11 ARAGÃO, Antônio F. Moniz de. A Bahia e seus governadores na República. Salvador: Uefs Editora, Fundação Pedro Calmon, 2010, p.619-623. A "colônia baiana" congregava integrantes das elites políticas e letradas, tais como senadores, deputados, ministros, funcionários públicos, suas famílias, parentes, aliados, de posições diversas, que deixavam a Bahia e se dirigiam ao Rio para assumir cargos, ou tentar um lugar ao sol nas suas concorridas, elegantes e higiênicas moradas. Habitavam em casas particulares, hotéis, pensões, e freqüentavam círculos de sociabilidade em que ocorriam recepções e reuniões para promover a Bahia ou tratar de matérias de interesse privado ou público. Formando uma rede seletiva de migração entre Rio e Bahia, recebendo e introduzindo na sociedade carioca seus patrícios ao mesmo tempo em que passava e recebia informações das capitais baiana e federal, a colônia desperta a investigação histórica. Encontram-se informações dispersas sobre ela em: CALMON, Pedro. Miguel Calmon. Rio de Janeiro: Livraria São José, 1983; PEIXOTO, Afrânio. Breviário da Bahia. Rio de Janeiro: Ministério da Educação e Cultura, Conselho Federal de Cultura, 1985, p.261 e 262; PINHO, Demósthenes Madureira de. Carrosse/ da vida. Rio de Janeiro: José Olympio, 1974, p.64, 65 e 66; p.81 e 110. 
da administração pública estadual e pelas dificuldades de representação da Bahia. O discurso eletrizou as oposições a Seabra, que se digladiavam com o governador seabrista Antônio Moniz. Também perturbou os anfitriões, que tinham visto em Rui um antídoto contra o facciosismo. Lamentando sua atitude, observaram que a obsessão por partidos entre seus conterrâneos parecia uma ironia do destino face às qualidades da terra natal. ${ }^{12}$

\section{Café contra leite}

Como não poderia deixar de ser, os estudos de Luís Henrique Dias Tavares e Consuelo Novais Sampaio vêm influenciando as pesquisas sobre a Bahia republicana. Em História da Bahia, ${ }^{13}$ Dias Tavares faz uma síntese cujo recorte se estendeu da conquista colonial lusa à Constituição de 1988. Na parte dedicada ao período 1889-1930, o livro narra acontecimentos políticos e caracteriza as condições sociais, demográficas e econômicas do estado explicando-os a partir de um aludido fiasco econômico em comparação, ora com São Paulo e Rio de Janeiro, ora com "os estados do sul", ${ }^{14}$ delineando uma relação estrutural entre as condições materiais da sociedade e a política. Em seu diagnóstico, o problema central é a estagnação industrial, atribuída ao predomínio asfixiante de capitais agro-mercantis e bancários e à convivência entre formas de trabalho livre e semi-escravo, que não geravam mercado interno e que mantinham a dependência do empregado perante o patrão. ${ }^{15}$ Essa visão é desenvolvida em O Problema da involução industrial da Bahia, em que o autor reafirma a incapacidade da indústria de trilhar um caminho autônomo mas em que também acrescenta um dado diferencial: a relativa importância do amplo comércio grossista centralizado em Salvador, por causa de seu porto, anotando que a Bahia contribuiu, entre 1889 e 1930, com divisas para a balança comercial brasileira. ${ }^{16}$

Comparar a economia baiana à dos estados do sul pode ser inadequado quando São Paulo, Minas e Rio de Janeiro são tomados uniformemente, pois não possuíam economias homogêneas, em termos de robustez e lucratividade. ${ }^{17}$ No Rio, por exemplo, a lavoura do café do vale do Paraíba não se

12 MELLO, Pimenta (ed.). Colônia baiana ao batalhão de atiradores. Rio de Janeiro: s.ed., 1917, p.26. O discurso de Rui está na p.18. Ver também: SAMPAIO. Partidos políticos na Bahia da Primeira República, p.98; e ARAGÃO, Antônio F. Moniz de. A Bahia e seus governadores na República, p.623. Segundo essa última fonte, nem mesmo conhecidos aliados de Rui, como o seu próprio filho Alfredo Rui e J. J. Palma, desejavam romper com o situacionismo seabrista naquele momento.

13 TAVARES, Luís Henrique Dias. História da Bahia. São Paulo/Salvador: Unesp/Edufba, 2008.

14 TAVARES, Luís Henrique Dias. História da Bahia, p.360 e 369.

15 TAVARES, Luís Henrique Dias. O problema da involução industrial da Bahia. Salvador: Edufba, 1966.

16 TAVARES, Luís Henrique Dias. O problema da involução industrial da Bahia, p. 28.

17 Sobre a diferença entre a cafeicultura dos três estados, ver: PIRES, Anderson. Capital agrário, investimento e crise na cafeicultura de Juiz de Fora, 1870-1930. Niterói: UFF, 1993 (História, Dissertação de mestrado), p.120 apud VISCARDI, Cláudia. O teatro das oligarquias, p.130. Para uma visão pouco conhecida da História econômica da Bahia, ver: JANCSÓ, István. As exportações da Bahia durante a República Velha. In: MAURO, Frederic (org.). L'Histoire quantitative du Brésil de 1800 a 1930. Paris: CNRS, 1973. RIDINGS, Eugene. Business interest groups in Nineteenth-Century Brazil. Cambridge: Cambridge University Press, 1994. 
equiparava em dinamismo às fazendas do Oeste paulista. Adicionalmente, no fim do XIX e início do XX, o cultivo do açúcar no norte fluminense passou por problemas sérios de depressão, similares aos da Bahia. ${ }^{18}$ Por outro lado, no início do século XX, a capital federal era mais industrializada que São Paulo (embora tenha sido depois superada pelos paulistas). De fato, o desenvolvimento de São Paulo durante a Primeira República o afastou cada vez mais do resto do Brasil e, por isso, sua comparação com a Bahia, como geralmente é feita, dificulta um cálculo preciso sobre a Bahia em relação, seja ao Brasil como um todo, seja perante os demais estados. Por fim, a visão estrutural de um sul em ascensão, em bloco, e de um nordeste em decadência (igualmente em bloco), ainda que não seja uma falácia, encobre o conflito de interesses gerado pelas diferenças existentes entre os estados, que nem sempre se alinhavam nos blocos nortista e sulista.

Em 1973, Consuelo Sampaio defendeu dissertação em seguida publicada sob o título Partidos políticos na Bahia da Primeira República, ${ }^{19} \mathrm{em}$ que analisou as várias, aguerridas e provisórias agremiações partidárias, tão devotadas a um chefe quanto organizadas com laços personalistas e de parentesco. Precisamente, a prática costumeira da "política de acomodação" no poder pela situação tinha por efeito semear a cizânia entre as facções. É nossa hipótese que essa política de acomodação eliminava a crença da oposição no rodízio das forças e, assim, desordenava a política no estado de modo característico, o que prejudicava a Bahia em nível nacional. Outrossim, Sampaio frisa que a subordinação dos setores produtivos à atividade comercial explica o mau desempenho econômico baiano, em particular $\mathrm{o}$ industrial. ${ }^{20}$

Num ensaio publicado em 1977, Sampaio escrevera que a evolução das "plantações cafeeiras do centro-oeste paulista" rumo a uma "estrutura capitalista" contrastava com a estagnação do vale do Paraíba (Rio de Janeiro) e dos estados nortistas, "esmagadoramente rurais e patriarcais", com suas "raízes no latifúndio colonial, alavancado pela mão-de-obra escrava". São Paulo, em decorrência, aparece como um estado todo-poderoso: não só destronou a monarquia em 1889 como também "firmou compromisso com Minas Gerais pela supremacia na política". Ainda mais, foi a causa da queda da Primeira República, ao insistir no nome de Júlio Prestes. ${ }^{21}$

Em 1978, veio à luz Coronelismo e oligarquias, do coreano Eul-Soo Pang. Este, ao ter em mente as condições gerais de uma nação como o Brasil do início do século XX, referindo-se à economia baiana, faz outra avaliação.

18 ANDRADE, Manuel Correia de. Modernização e pobreza: a expansão da agroindústria canavieira e o seu impacto ecológico e social. São Paulo: Unesp, 1994, p.65 e ss., 93 e ss. FERREIRA, Marieta de M. Em busca da Idade do Ouro. Rio de Janeiro: Editora da UFRJ, 1994, p.22, 38, 49.

19 SAMPAIO, Consuelo Novais. Partidos políticos na Bahia da Primeira República.

20 SAMPAIO, Consuelo Novais. Partidos políticos na Bahia da Primeira República, p.27 e p.39.

21 SAMPAIO, Consuelo Novais. Formação do regionalismo no Brasil. Salvador: Centro de Estudos Baianos, 1977, p. $8,9,11,13$. 
Informa que "sua importância econômica (açúcar e cacau na costa, gado e mineração no interior)", ao lado do seu tamanho, sua população, e suas personalidades destacadas, "fizeram da Bahia um importante estado secundário na hierarquia política". Em segundo lugar, a análise de Pang sobre o coronelismo não adota a perspectiva estrutural porque - argumentando que "a quintessência da Primeira República foi o processo de harmonizar as reivindicações conflitantes das oligarquias" - propõe investigar como se deu a resolução de conflitos regionais no interior do sistema federalista. No lugar de fecharem um circuito exclusivo entre eles, paulistas, mineiros e gaúchos tinham de "integrar" os demais estados. Sua pesquisa revela que os mais fortes buscaram contemporizar os seus interesses com os de outros estados de outras regiões, mediante alianças nas quais nem sempre paulistas e mineiros couberam lado a lado, apesar - claro - de a soma de ambos poder ocasionar poderosas coligações. Diante da alta freqüência das alianças e das disputas entre as oligarquias, sobressaem seus interesses diversos e atritantes, e não sua impotência. Pang, enfim, também destaca que um olhar atento sobre a relação entre pecuaristas mineiros e cafeicultores paulistas distinguiria uma política de "café contra leite", dada a competição entre eles pela hegemonia sobre a República, principalmente a partir de $1910 .{ }^{22}$

O livro de Pang não deu maiores frutos até ser divisado pela pesquisa de Viscardi, que dirigiu sua argúcia para o nível nacional (o que, decorrentemente, abre a possibilidade para o estudo da Bahia republicana ir além da mãe paralítica a reboque de Minas e São Paulo). Tal abertura é essencial para entendermos com maiores detalhe e certeza o papel da Bahia no jogo federativo da Primeira República. Questionando quanto havia de "hegemônico, permanente e isento de conflitos" na prática "política do café-com-leite", Viscardi revê seu alcance explicativo para o entendimento do federalismo. ${ }^{23}$ Ao anotar que a República era controlada por seis estados hierarquizados entre si, que formavam alianças mutáveis e dinâmicas (e assim mobilizavam as unidades subalternas), a São Paulo, Minas e Rio Grande do Sul são somados Rio, Bahia, e Pernambuco. Juntos, ocupavam mais de $60 \%$ das cadeiras do Parlamento e seus produtos - café, açúcar, cacau, fumo, algodão, charque, couros - lideravam as exportações. Os três mais fortes possuíam bancadas grandes e economias fortes. Já os intermediários tinham um dos dois atributos. No caso da Bahia, coube-lhe a segunda maior bancada do Congresso (igual número de cadeiras foi reservado aos paulistas), ${ }^{24}$ vantagem passível de ser desfeita em coesão e força (logo, peso e importância) ao ecoar os entrechoques de suas lutas

22 PANG, Eul-Soo, Coronelismo e oligarquias 1889-1934, p.8 e 9

23 VISCARDI, Cláudia. O teatro das oligarquias, p.19.

24 VISCARDI, Cláudia. O teatro das oligarquias, p.53. 
internas, o que podia ser decisivo em processos de escolha para comissões no parlamento, por exemplo. Durante os primeiros 14 anos do século XX, afora ministérios militares, líderes baianos receberam postos ministeriais significativos mais de uma vez: a Justiça ou Indústria, Viação e Obras Públicas; instâncias importantes para a condução de negócios políticos ou contratos e obras públicas. Sem nada entre 1914 e 1922, a Bahia, mesmo na mira de Artur Bernardes, que atacou o governador J. J. Seabra, viu Miguel Calmon subir ao Ministério da Agricultura, Indústria e Comércio (1922-1926), o que voltou a alinhar o estado com o centro da política nacional - tarefa depois encomendada a Otávio Mangabeira, ministro das Relações Exteriores de Washington Luís. ${ }^{25}$ De fato, depois da morte de Rui e do declínio de Seabra, calmonistas e mangabeiristas consistiam nas principais facções que ligavam o estado à capital.

Esta posição de importante estado secundário, conforme assinala Pang, ao ser regularmente contrastada com a superioridade da Bahia no Segundo Reinado, foi diluída numa visão incompleta sobre o que significa ser secundário na República. ${ }^{26}$ Mário A. da S. Santos, contudo, nos instiga a explorar a sugestão de que o saudosismo monarquista, entre os políticos baianos, fez a importância da Bahia parecer menor do que de fato era. ${ }^{27}$ Ser um estado secundário na federação brasileira era integrar um grupo de atores cujas opiniões e negócios eram levados em conta nas barganhas e alianças, graças à sua importância econômica ou política. Ou mesmo graças à influência pessoal de Rui, Calmon ou Seabra - os três maiores expoentes da "colônia baiana" no Rio, secundados, seja pelos governadores estaduais, seja pela estrela ainda em ascensão de Otávio Mangabeira, mais jovem e de abrangência menor.

Conforme Viscardi, os estados que, nas prévias das campanhas presidenciais, se encontravam mais robustos, reuniam as melhores condições de interferir no rumo dos acontecimentos. $E$ isto tinha conseqüências diretas na obtenção de financiamentos e fundos para suas atividades econômicas. Mesmo assim, Ferreira demonstra que o fato da Bahia e do Rio de Janeiro estarem constantemente assolados por divisões internas não impediu que ambos tivessem participação ativa nos processos sucessórios. ${ }^{28}$ Quanto à Bahia em particular, é nossa hipótese que seu peso teria sido ainda mais saliente se não se verificassem tantas desavenças e cismas e, ainda mais, se não fosse bifurcada entre Rui e Seabra. Em acréscimo, uma pesquisa comparativa sobre Bahia e Pernambuco poderá revelar que as usinas de

25 SARMENTO, Sílvia. A raposa e a águia, p.57.

26 SAMPAIO. Partidos políticos na Bahia da Primeira República, p.31; SAMPAIO, Consuelo. Formação do Regionalismo no Brasil, p.13. SILVA, Paulo Santos. Âncoras da tradição. Salvador: Edufba, 2000, p.15. SARMENTO, Sílvia. A raposa e a águia, p.16; LEITE, Rinaldo. A rainha destronada. São Paulo: PUC, 2005 (História, Tese de doutorado). 27 SANTOS, Mário Augusto Silva. O movimento republicano na Bahia. Salvador: Centro de Estudos Baianos, 1990, p.17.

28 VISCARDI, Cláudia. O teatro das oligarquias, p.42. FERREIRA, Marieta de M. Em busca da Idade do Ouro. 
açúcar e a indústria têxtil do Leão do Norte eram de maior compleição do que as baianas. E nem por isso Pernambuco foi a todo instante de maior relevo, na política, do que a Bahia. Outrossim, mesmo que tenha sido mais desenvolvido que a Bahia quanto à sua economia industrial, Pernambuco não deixou de ser tratado por Robert Levine como um "caso típico de decadência, política e econômica" da região Nordeste. ${ }^{29}$ Para nós, ao contrário, o caso da Bahia não é o ocaso da Bahia apenas. Igualmente, a região quando ela existiu - não era homogênea nem pode ser vista apenas pelo prisma uniformizador de sua decadência. A política, enfim, se vale de outros recursos de poder afora o econômico.

É aliás possível perceber, em Levine, que a política brasileira não é acompanhada do mesmo jeito pelos estados exatamente porque seus percursos são diversos e atritantes entre si. Assim, está posta a necessidade de conhecer de forma minuciosa as suas trajetórias e interações. Por exemplo, o fortalecimento de Seabra no Rio como aliado do presidente Hermes aprofundou as vicissitudes dos baianos em seu estado, pois levou-os a uma nova divisão local, que refletia o incerto relacionamento entre Rui e Seabra. Os gaúchos, em contraste, passavam a formar um partido coeso, e assim rompiam com a prática de Júlio de Castilhos de isolamento do estado ante os primeiros governos republicanos, como indica Joseph Love. Com Pinheiro Machado, os gaúchos superaram parte de seus conflitos internos e ultrapassaram a Bahia no posto de terceira força política nacional. Em paralelo, infiltraram-se em território caro ao Recife: os estados nortistas de menor porte. O fato de os gaúchos terem pretensões de domínio sobre o Norte nos leva a pensar que os sulistas viam um objeto de desejo e, por conseguinte, cobiçavam algo que era dos nortistas. O que podemos frisar, desde já, é a conveniente simultaneidade entre a intervenção de Hermes em Pernambuco e o assédio dos gaúchos sobre o Norte. Lendo Levine e Love sem os antolhos do café-com-leite, especulamos que o mesmo presidente - Hermes da Fonseca - que interferiu em Pernambuco, derrubando Rosa e Silva, não pôs cabrestos nas ambições de Pinheiro Machado. ${ }^{30}$ Coincidentemente, à pequena representação gaúcha nos ministérios de 1894 a 1910 seguiu-se, então, o jejum baiano, ocorrido entre 1912 a 1922. No lugar de uma transferência rápida e total de poder do Norte para o Sul, ocorreu uma disputa complexa e intensa, o que exigiu empenho da parte dos atores.

29 Os políticos baianos, entre 1889 e 1930, em comparação com pernambucanos, participaram com mais regularidade na escolha prévia de candidatos às eleições presidenciais. Ver: VISCARDI, Cláudia. O teatro das oligarquias, p.64. É claro, por outro lado, que Pernambuco dispunha de nomes como Rosa e Silva e Estácio Coimbra, dentre outros, LEVINE, Robert. A velha usina: Pernambuco na federação brasileira, 1889-1937. Rio de Janeiro: Paz e Terra, 1980, p.19. Sobre a indústria açucareira e têxtil no Brasil e em seus estados, ver: ALBES, Edward. Cane sugar in Pan America. Bulletin of the Pan American Union, v.39, p.634 e ss., 1914; SCHURZ, W. L. The Brazilian sugar industry. Bulletin of the Pan American Union, v.58, p.369-374, 1924; STEIN, Stanley J. The Brazilian cotton manufacture: textile enterprise in an underdeveloped area, 1850-1950. Cambridge: Harvard University Press, 1957

30 LEVINE, Robert. A velha usina, 1889-1937, p.20; e LOVE, Joseph. O regionalismo gaúcho e as origens da revolução de 1930. São Paulo: Perspectiva, 1975. Capítulos 5 e 6 
Outro proveitoso argumento que cabe aqui sublinhar é o da autonomia relativa do Estado Nacional ante os cafeicultores. A importância da política fiscal, cambial e monetária para economias voltadas para o mercado externo fez do controle do Estado um alvo fixo para os fazendeiros do café. Entretanto, as disputas por hegemonia e a necessidade de agregar interesses de outros estados impediram um controle monolítico do aparelho estatal pelos paulistas. ${ }^{31} \mathrm{Nem}$ por isso devemos esquecer a fórmula que viabilizou a imigração italiana em massa para as fazendas de café. Transferindo para o Estado os custos, os problemas e os riscos da empreitada imigrantista, reservou os lucros aos particulares, os plantadores. ${ }^{32}$ Outrossim, cabe recordar que, enquanto progredia a cafeicultura do oeste paulista, o café do Vale do Paraíba fluminense ficava para trás. A cafeicultura no dito Sul, em resumo, não era regionalmente uniforme.

A feitura e o desmanche das redes tecidas entre as elites políticas nos intrigam a querer saber mais, o que singulariza as associações dos estados na cena política. Não corroboram, portanto, a imagem de uma República exclusiva do café-com-leite, em parte tributária de uma concepção em que o político é servil ao econômico, o que tende a absolutizar São Paulo, ao invés de reconhecer a diversidade vigente. Para nós, a fragilidade políticainterna e nacional - da Bahia, no lugar de ser reflexo da economia, pode ter prejudicado suas atividades econômicas, dada a desvantagem na hora de obter e gerir os recursos federais. Deste modo, no lugar de vermos a Bahia como um estado atrasado e marginal, cabe investigar em que medida os problemas que as elites políticas baianas viveram - na hora de se colocar à frente dos outros estados - não foram devidos às suas disputas intestinas.

Note-se ainda a cacauicultura, vigente no sul do estado. Se Pang aludiu ao café contra leite, é possível especular se existiu, na Bahia, açúcar contra cacau - e aqui falamos de disputas entre plantadores do mesmo solo. Por um lado, Freitas afirma que as oligarquias de llhéus e Itabuna jamais foram hegemônicas na política baiana, não obstante o fruto do ouro carrear as exportações do estado no início do século XX. Já Falcón acrescenta que onerando o cacau - a açucarocracia do Recôncavo baiano (e não de outro estado) mitigou as dores de sua incapacidade em adentrar o processo de industrialização do açúcar. ${ }^{33}$ Logo, não só o mais rico não obtinha adequada expressão como também foi taxado pelos que detinham poder e representação, vistos, em geral, como decadentes e nostálgicos do braço escravo. Como se vê, na condução dos negócios internos, há segredos da política para a pesquisa investigar.

31 VISCARDI, Cláudia. O teatro das oligarquias, p.22.

32 HALL, Michael. Trabalhadores Imigrantes. Trabalhadores, Campinas, n.3, p.4-14, 1989

33 FALCÓN, Gustavo. Coronéis do cacau. Salvador: lanamá, 1995, p.11 e ss., p.34. 
Em acréscimo, não se trata de ensimesmar a História política em peculiaridades mantidas imune a comparações. A referência à marginalidade e frustração da Bahia e suas elites pode ser abordada por meio de certos contrastes. Minas Gerais, tal como a Bahia, não só não dispôs de um movimento republicano forte antes da Proclamação como teve de esperar cerca de 15 anos após 1889 para angariar suficiente coesão entre suas elites e assim assumir o papel de liderança que - a partir de Afonso Pena, apoiado pela Bahia - caracterizou os mineiros. Apesar do prestígio dos fluminenses Quintino Bocaiúva e Silva Jardim no movimento republicano, o republicanismo na província do Rio de Janeiro permaneceu vegetativo até 1888 (isto para não citar os muitos partidos criados e dissolvidos, personalistas e fracos institucionalmente, como os baianos). Atraso social em relação a um sul progressista é a explicação dada para a não execução do imposto territorial na Bahia. Vale notar que sua cobrança também encontrou obstáculos em São Paulo e Minas Gerais. ${ }^{34}$

Outrossim, a lamúria de que os baianos não dispunham de um líder de estatura além de Rui Barbosa deve ser confrontada com a figura do gaúcho Pinheiro Machado, para o qual o Rio Grande do Sul não dispunha de um substituto quando do vazio deixado por sua morte em 1915. Já os baianos, quando Rui faleceu em 1923, além de Seabra, se valeram de Miguel Calmon, que era certeza de reforço em cenário republicano cujos próceres principiavam a falecer. Miguel Calmon, aliás, era um recurso duplo de portabilidade: transferiu tanto tradições do Brasil imperial para o republicano quanto poder da Bahia para o Rio.

Sem negar que houve declínio político e econômico, esse artigo propõe considerar que a tradição baiana de ter sido no Império o "berço dos grandes estadistas" - a "Virgínia Brasileira" - de alguma maneira perdurou na República, desde as suas origens, prolongando-se no tempo (para o que a efeméride de 1908 foi um ponto destacado). Em uma de suas viagens à sua cara cidade da Bahia - Salvador -, Freyre escreveu em 1945 que, mesmo não havendo um presidente baiano, ainda assim os chefes do estado eram ouvidos na condução dos negócios políticos. ${ }^{35}$ Por sua vez, Sérgio B. de Holanda, ao aludir à proeminência de baianos nos gabinetes imperiais, sugeriu que a educação era um dado importante para entender o fenômeno. Segundo ele, a Bahia (assim como o Maranhão) enviou muitos bacharelandos à Universidade de Coimbra; e seus filhos, dessa maneira, estavam entre os mais bem instruídos. Ao longo do século XIX, essa proeminência

34 Sobre as divisões internas e a fraqueza do movimento republicano em Minas e Rio de Janeiro, ver, respectivamente, VISCARDI, Cláudia. O teatro das oligarquias, p.76-80; e FERREIRA, Marieta de M. (org.) A República na velha província. Rio de Janeiro: Rio Fundo, 1989, p.32-36. Sobre a fraqueza dos partidos republicanos fluminenses, ver: FERREIRA, Marieta de M. Conflito regional e crise política: a reação republicana no Rio de Janeiro. Rio de Janeiro: CPDOC, 1990, p.32. Sobre o imposto territorial em São Paulo e Minas, ver VISCARDI, Cláudia. O teatro das oligarquias, p.142 e 145.

35 FREYRE, Gilberto. Bahia e baianos. Salvador: EGBA, 1990, p.67. 
foi capaz, segundo o autor, de se manter de pé mesmo frente à ascensão econômica das regiões cafeeiras. Em suas palavras, a presença de baianos em ministérios manteve-se "inexpugnável" muito embora situassem-se no sul as mudanças "destinadas a alterar a fisionomia tradicional do país". ${ }^{36}$

Apreciadores da oratória, os baianos, em seus discursos, referiam-se ao papel de seu estado na história, o que parece um indício de que a tradição era algo relevante para a audiência, não sendo esta última exclusivamente de nativos. Adicionalmente, logo após 1889, qualquer que tenha sido o rebaixamento que a Bahia sofreu, foi atenuado pela presença, seja de Rui nos cargos de vice-chefe e ministro da Fazenda de Deodoro, seja de Manoel Vitorino na vice-presidência e na presidência interina do primeiro governo civil (em aliança com os paulistas). No Congresso, o estado conservou uma bancada de peso (menor apenas do que a mineira) e ocupou presidências de comissões. ${ }^{37}$ Nas sucessões dos primeiros governos civis, os baianos exerceram papel saliente. Posteriormente, as candidaturas à Presidência de Rui (1910 e 1919) e de Seabra à vice-presidência pela Reação Republicana (1921), assim como a de Vital Soares (1930), coligado a Júlio Prestes, evidenciam que a Bahia e seus políticos não eram cartas jogadas fora do baralho. Ao contrário, renovaram o papel dos baianos quando as disputas políticas de fato contrapuseram situação e oposição. Quando listados juntos dos nomes dos outros vice-presidentes, os baianos aparecem em meio a dois pernambucanos (Rosa e Silva, Estácio Coimbra), uma alagoano (Floriano) e um maranhense (Urbano Santos), o que induz a pensar no peso político dos nortistas - e não em sua prostração. Os demais vice-presidentes foram mineiros ou fluminense, não constando paulistas ou gaúchos...

Logo, o "importante é perceber", como afirma Viscardi, que "a Bahia sempre se fizera presente", não obstante seu frágil movimento republicano antes de 1889. "Em função de sua bancada numerosa, somada à tradição herdada de ter sido importante Província no período imperial", o estado participou dos "primeiros anos do regime republicano e aspirava a aumentar este poder". Esta aspiração foi porém desarrumada tanto pelos duelos de Rui e Seabra quanto pela política de acomodação que as elites baianas encetavam ao subirem ao poder. Veja-se que, quando menos desarranjadas, as elites baianas lograram resultados, amealhando a Vice-Presidência de Prudente de Morais e de Júlio Prestes. Em ambos os casos, São Paulo estava coligado com a Bahia - e não com os mineiros. No caso do processo sucessório que elegeu Prudente, a Bahia exercia "papel político muito mais ativo do que o desempenhado por Minas". No caso do pleito de 1930, Minas

36 HOLANDA, Sérgio B. de. Do Império à República. In: História Geral da Civilização Brasileira, tomo II, v.5, n.7. São Paulo: Difel, 1972, p.271, 273 e 274.

37 Na feitura de comissões, a Bahia, ao longo da Primeira República, perdeu posições importantes graças à interferência do senador gaúcho Pinheiro Machado. VISCARDI, Claudia. O teatro das oligarquias, p.53, 59 e 60. 
e Rio Grande do Sul estavam na oposição contra as pretensões de São Paulo, que encontrou na Bahia um aliado importante. Não por acaso, o seu papel pouco teve de conspirativo. Como ensina Luís H. Dias Tavares, os Calmon "fecharam o estado da Bahia para a campanha da Aliança Liberal". ${ }^{38}$

Vale a pena, mesmo assim, aditar indícios arquivísticos que levam a indagar do papel de Seabra na órbita do tenentismo e identificar razões do supracitado fechamento. Um observador da diplomacia estadunidense notou, em 1923, as suspeitas de sua implicação com o motim do forte de Copacabana de 1922. Esmagado o levante, o pernambucano Estácio Coimbra sucedeu o maranhense (e falecido) Urbano dos Santos como vice-presidente, cargo pelo qual Seabra lutara "desesperadamente". De fato, consta em ofício sobre o inquérito policial acerca desse "pronunciamento militar" ter sido a revolta derivada, segundo os "boatos" então correntes, "de combinações previamente assentadas entre civis e militares", almejando depor o presidente e substituí-lo por uma "junta governativa" integrada pelo marechal Hermes, Nilo Peçanha e J. J. Seabra. Dez anos depois de ser feito governador da Bahia pelos balaços de canhão municiados pelo então presidente Hermes, Seabra figura em investigações sobre tomada do poder em parceria com o mesmo Hermes e Nilo Peçanha, ao lado de quem se batera pela Reação Republicana. Por outro lado, em 1926, a embaixada dos EUA notou que, na composição do gabinete Washington Luís (que tomou o cuidado de "dividir os postos entre os estados mais importantes"), a indicação de Otávio Mangabeira foi a única prevista nos círculos políticos, em parte por causa de sua atuação na Câmara dos Deputados a propósito da reforma da Constituição na qual, dentre outras providências, propôs limitar os direitos políticos dos dissidentes civis e militares de 1922 e 1924. ${ }^{39}$ Conforme carta do presidente da Câmara dos Deputados Arnolfo Azevedo ao presidente Washington Luís em 1926, o federalismo da I República, do qual São Paulo havia sido o expoente de primeira hora, supunha um vínculo entre os jogadores cujo rompimento era o fim do próprio jogo. "No baralho político há três ases e três reis". "Quem vai dirigir o jogo precisa ganhar a partida e para ganhá-la é indispensável ter dois ases e um rei" (sendo os ases Minas, São Paulo e Bahia e os reis, Pernambuco, Rio e Rio Grande do Sul). "Sentar-se à mesa do jogo sem contar com esses trunfos é arriscado e quem tiver a maioria absoluta dos seus valores fará, não só um governo bom, mas ótimo e fácil" ${ }^{40}$ Por fim, quando a revolução estourou, as tropas legalistas foram concentradas ao sul em São Paulo

38 VISCARDI, Cláudia. O teatro das oligarquias, p.36 e 97; TAVARES, Luís Henrique Dias. História da Bahia, p.479. Ver também: FREITAS, Alexandra. Alcance e limites do tenentismo na Bahia. Salvador: UFBa, 2010 (História, Dissertação de mestrado).

39 Arquivo Edgard Leuenroth (AEL). Despacho do Consulado de Salvador. 20/04/23, no 193. Ofício, 22/11/1922; Museu Histórico Nacional, Coleção Nilo Peçanha. Lata 37, P 1, n.27; AEL. Despacho da Embaixada. 16/10/26, n.2677, p.2.

40 Arquivo Público do Estado de São Paulo (APESP). Arquivo Washington Luís. Carta, 26/4/26. Caixa 188, pasta 1, documento 56. 
e ao norte na Bahia. Tudo somado, é possível entender melhor a blindagem com que os Calmon quiseram cercar a Bahia ante o mudancismo de 1930.

O que os baianos também podiam cacifar era o seu cabedal na cultura política bacharelística e oligárquica (no qual a palavra escrita e falada possuía papel central). Em tal meio, a instrução permaneceu crucial. O caso de São Paulo, como era de se esperar, apresenta-se em termos excepcionais. Segundo Love e Barickman, apesar de combinar-se com a instrução, "a proeminência econômica claramente aparenta ser o traço mais distintivo dos paulistas, ao menos quando comparados com outras elites políticas brasileiras". ${ }^{41}$ Eram proprietários e bem instruídos, e isto lhes era específico. Já os baianos, que não eram proprietários como os paulistas (embora não fossem destituídos de fábricas, bancos, fazendas, firmas, comércio), haviam sido os fundadores da primeira Faculdade de Direito criada na República (1891), depois das imperiais escolas de São Paulo e Recife.

O elo entre tradição e instrução fica claro em Miguel Calmon. Aos 23 anos, em 1902, já professor da Escola Politécnica da Bahia, foi nomeado secretário da Agricultura pelo governador Severino Vieira, conservando-se no cargo após a sucessão de quem o convocara. Em 1906, na volta de uma viagem à Ásia (onde averiguou matérias sensíveis como o problema da mão-de-obra rural e a competitividade das lavouras estrangeiras), tornou-se ministro da Indústria, Viação e Obras Públicas do governo Afonso Pena, consagrando-se como o mais jovem ministro da República. Sua presença como ministro da Agricultura e amigo íntimo, nos funerais de Rui em 1923, lançou-o como herdeiro do chefe. Aliar instrução, altivez, refinamento, cosmopolitismo, ao nome da família foi o modo pelo qual Miguel Calmon atualizou o modelo deixado pelos antigos estadistas baianos do Império. Seu tio, o marquês de Abrantes, de quem herdou o prenome, representara um tipo de estadista para o qual "educação refinada, origem aristocrática, acesso regular à Europa, introjeção dos modernos ideais do ocidente, notadamente civilização e progresso" eram traços constituintes de sua identidade e ferramentas para a missão a ser cumprida. ${ }^{42}$ Para Regina Abreu, os setores aristocráticos, Miguel Calmon à testa, criaram um estilo de vida e um modelo de atuação que na República não se extraviaram - inclusive porque os baianos não estavam liquidados.

\section{Bahia inundada de luz}

Seja pelo dom da fala, seja pelas letras cultivadas, seja por sua astúcia, os baianos não deixaram passar despercebida nem cair no esquecimento

41 LOVE, Joseph L.; BARICKMAN, Bert J. Rulers and owners. Hispanic American Historical Review, v.66, n.4, 1986, p.747, 757.

42 ABREU, Regina. A fabricação do imortal. Rio de Janeiro: Lapa/Rocco, 1996, p.51-52. 
a breve permanência, não mais que uma semana, da família real lusa na cidade da Bahia. Embora o Rio tenha sido o destino definitivo (a capital da América Portuguesa fora transferida, no século XVIII, para o mesmo Rio), a Bahia se fez marcante. A começar pela figura de proa do visconde de Cairu, José da Silva Lisboa, decisivo para o decreto de abertura dos portos, editado em Salvador, a Bahia foi uma das vedetes do centenário de 1808. Ocorrida no Rio, que aliás já era a vitrine de um país que ansiava por "progresso", ${ }^{43}$ a Exposição Nacional foi montada numa cidade que, depois das obras de Pereira Passos, dispunha - pela avenida Central - de arruamento largo e retilíneo da praça Mauá ao palácio Monroe, assim como entre o Monroe e a praia Vermelha (onde a feira foi instalada) via avenida Beira-Mar. Em seu lábaro estrelado, a Bahia brilhou. Não só a iconografia o retrata como também o demonstra a incumbência de Miguel Calmon, membro do Diretório Executivo. No entanto, é mais profícuo percebê-lo como ponto nodal de uma rede do que nos encerrarmos nas loas à sua estirpe. Em suas decisões e atitudes, trajetória e rede interpessoais, vemos a possibilidade de analisar como, na Primeira República, as elites da Bahia fizeram-se ouvir entre suas congêneres e, em acréscimo, conservaram o seu prestígio.

Por um lado, Miguel Calmon, residente em seu palacete em Botafogo (a algumas quadras de Rui), era um vértice na triangulação entre o banqueiro Góis Calmon e o chefe político Antônio Calmon. Enquanto Góis "representava uma extensa rede das elites econômicas baianas, cujos interesses comuns iam do açúcar aos bancos", Antônio, num exagero à sua performance, foi definido como "precursor da política populista". Uma proeza sua (fixada na memória) foi a compreensão familiar, nas eleições para a assembléia estadual de 1935, de que deviam desfraldar "a sua bandeira", hasteando o sobrenome ilustre. Antônio não admitiu que "fosse uma manifestação modesta". "Ignorando o eleitorado", colocou "na cabeça da chapa" o jovem Pedro. Resultado, seu candidato Pedro Calmon - o grande historiador - foi "o mais votado da Bahia!" . ${ }^{44}$ Antônio elegeu nomes e ignorou o eleitorado sem que os candidatos precisassem domar suas reservas elitistas, ao se avizinharem de eleitores pobres e negros, invariavelmente tratados com paternalismo. A raiz eleitoral do calmonismo oferece, assim, um bom exemplo da capacidade das elites baianas de adaptarem-se aos novos tempos, conservando suas prerrogativas após extinta a escravidão

43 BENCHIMOL, Jaime. Pereira Passos, um Haussmann tropical: a renovação urbana do Rio de Janeiro no início do século XX. Rio de Janeiro: Secretaria Municipal de Cultura, 1990. Sobre o contraste entre um Rio velho e novo após os "melhoramentos" empreendidos no início do século XX, ver: LLOYD, Reginald. Impressões do Brasil no Século Vinte: sua história, seu povo, comércio, indústrias e recursos. Londres: Lloyd's Greater Britain Publishing Company, 1913, p.481-501.

44 PANG, Eul-Soo Pang. Coronelismo e oligarquias 1889-1934, p.178; PINHO, Demósthenes Madureira de. Carrossel da vida, p.90; CALMON, Pedro. Miguel Calmon, p.4, 164 
e a República ter implantado um sistema cujo pressuposto básico era a igualdade entre cidadãos tão diversos na raça e na classe social. ${ }^{45}$

Por outro lado, Miguel era um ator na colônia baiana carioca. Esta última, que se irradiava para além do alcance dos Calmon, não se munia apenas com residentes, mas também de visitantes, vendo-se ambos nas fotos celebrativas e nos trabalhos da exposição de $1908 .{ }^{46} \mathrm{O}$ ex-governador José Marcelino de Souza, o deputado estadual João Mangabeira, o literato Afrânio Peixoto, dentre outros, posaram, prosearam e interferiram. Grande azáfama ocupou também o prefeito do Rio Sousa Aguiar, baiano de nascimento. O senador Rui e o ex-ministro da Justiça J. J. Seabra, que era membro da comissão incumbida de representar o estado na mostra, igualmente aproveitaram essa oportunidade ímpar para aparecer.

Exprimir-se é um talento que várias gerações de baianos possuem, nos mais diversos campos; em diferentes tempos e lugares. Cabe investigar, pois, sua capacidade de posicionar-se; a exemplo da que Demósthenes Madureira de Pinho, nas suas idas à capital, encontrou em João Mangabeira. Com dom "extraordinário e aquela capacidade de caricaturar situações, sem que o traço do ridículo jamais atingisse a verrina", o irmão de Otávio desafiava as razões de seu oponente, quase troçando, a ponto de persuadir ser inútil uma tentativa de defesa ou de esclarecimento. ${ }^{47}$ Este esgrimir e o trânsito entre Salvador e Rio pouco têm a ver com elites abatidas e negligenciadas. Antes, parece que João Mangabeira preferia era a peleja, para poder desembainhar o seu jeito ladino. É este recurso - imaterial - que também está no legado que os veteranos e proeminentes conselheiros de Pedro II deixaram ao alcance de seus epígonos sem fortuna. Sem fortuna, mas não desafortunados.

É verdade que nem todos gostavam do falatório dos baianos. Freyre, por exemplo, detestava a oratória de Rui e Otávio Mangabeira. No seu modo de ver, em seu afã de trajarem roupagem "'moderna' e 'européia'", encobriam a "originalidade magnífica" de sua terra. Essa afetação das elites da Bahia remete à sua familiaridade e gosto com banquetes de cardápio em francês ao passo em que, sem rodeios, cultivavam o apreço à culinária posta na mesa por negras da cozinha, empregadas de seus casarões. $O$ próprio Freyre - igualmente ele sem peias - vive a mesma dualidade. Com sua erudição, resumiu em francês seu apego pela Bahia numa só frase: "une cuisine et une politesse!". "Duas expressões da civilização patriarcal" vicejavam em Salvador "como em nenhuma parte do Brasil", escreveu ele após ter se demorado na capital soteropolitana, em 1930, antes de partir

45 Ver ALBUQUERQUE, Wlamyra Ribeiro de. O jogo da dissimulação: : abolição e cidadania negra no Brasil. São Paulo: Companhia das Letras, 2009

46 SOUSA, Maria Mercedes. Rui Barbosa e José Marcelino. Rio de Janeiro: Casa de Rui Barbosa, 1950

47 PINHO, Demósthenes Madureira de. Carrossel da vida, p.90. 
para o exílio em Portugal. "Foi a Bahia que nos deu alguns dos maiores estadistas e diplomatas, do Império; e os pratos mais saborosos da cozinha brasileira em lugar nenhum se preparam tão bem como nas velhas casas de Salvador e do Recôncavo". ${ }^{48}$ Esta capacidade dos baianos de impressionarem visitantes e observadores guarda proximidade com o objetivo da viúva de Miguel Calmon, Porciúncula, quando resolveu doar acervo pessoal de seu esposo ao MHN em 1935. Como sintetizou Regina Abreu, tratava-se de fabricar um imortal. O que encontramos em 1908, na deliberação de firmar monumento à Bahia, é a mesma busca de consagração e reciclagem. ${ }^{49}$ Se, em 1908, o estado se valeu de Miguel Calmon, em 1935, sua viúva fez a doação de suas riquezas sob as juras de Gustavo Barroso, diretor do $\mathrm{MHN}$, e sob as vistas metódicas e leais do jovem Pedro Calmon (sem falar no mordomo que a representou diretamente).

Familiarizada com o Brasil e América Latina, a viajante e geógrafa Marie R. Wright não só conheceu o Rio antes e depois do "bota-abaixo" de Pereira Passos como também voltou ao país para percorrer a exposição de 1908 desta vez um bota-para-expor. Seguindo o protocolo, em 11 de agosto, o presidente Afonso Pena declarou aberta a mostra a rogo de Miguel Calmon. O significado desta cerimônia não passou despercebido aos observadores estrangeiros, garantiu Wright. Como que atravessando um rito de passagem, o Brasil deixava de ser a "terra do amanhã" e se inscrevia entre "as mais progressistas 'terras do hoje'". ${ }^{50}$ Com imagens que se encaixam com o que Wright assevera, ao percorrermos o acervo fotográfico do alagoano Augusto Malta, é possível notar um contraste entre os quiosques do centro da cidade (classificados pelas autoridades como ponto de infestação das classes perigosas) e os instantâneos batidos pelo retratista, que capturam moças elegantes em conversação descontraída, feira na qual havia quiosques igualmente, mas obviamente acorridos por esta clientela correspondente ao novo Rio que se queria instituir. Este Rio do início do século XX era tão arrebatador que inclusive atraiu um crítico do europeísmo. Em Ordem e progresso, Freyre comenta o afluxo de hóspedes dos hotéis "ávidos" por conhecerem os pavilhões da Exposição Nacional e as obras que "vinham modernizando" a capital. ${ }^{51}$ "Acabando com os quiosques", alargando ruas para abrir avenidas, "destruindo os chamados pardieiros", substituindo sobrados por edifícios, as "maravilhas de art nouveau" extasiavam homens e mulheres que, incomodados com as classes subalternas nas ruas, não abriam mão de passear e divertir-se nos logradouros públicos.

48 FREYRE, Gilberto. Bahia e baianos, p.27, 9.

49 ABREU, Regina. Fabricação do imortal, p.18, 81-82.

50 WRIGHT, Marie Robinson. The New Brazil, its resources and attractions, historical descriptive and industrial. Filadélfia: G. Barrie \& Sons, 1901; WRIGHT, Marie Robinson. The New Brazil, its resources and attractions, historical descriptive and industrial. Filadélfia: G. Barrie \& Sons, 1907 (segunda edição revista e ampliada); WRIGHT, Marie Robinson. The Brazilian National Exposition of 1908, p.37.

51 FREYRE, Gilberto. Ordem e progresso. São Paulo: Global Editora, 2004, p.716. 
A cada estado foi encomendada a missão de apresentar-se com todas as suas riquezas, atiçando o orgulho local de suas elites. Nesse sentido, é claro que Miguel Calmon não esteve sozinho em cena. Mesmo assim, ao sentar-se à esquerda do presidente durante o cerimonial de abertura, à direita estava o barão do Rio Branco (filho do baiano visconde do Rio Branco). Os estados responderam não só com as provas palpáveis de seus avanços como também expuseram "recursos naturais jazendo à espera do desenvolvimento". Para Wright, o efeito geral era um entusiasmo contagiante de "progresso". ${ }^{52}$ Após o portão de entrada, à direita postavam-se os pavilhões do Distrito Federal e da Bahia. À esquerda, mais atrações: São Paulo, Minas Gerais e o palácio manuelino, que os portugueses aprontaram. O Palácio das Indústrias localizava-se no fundo. Notório pelo seu parque manufatureiro e fabril, o Rio sobressaía por causa de suas usinas têxteis, estabelecimentos que comprovavam que o setor "tinha se desenvolvido mais do que qualquer outro" entre os ramos industriais brasileiros. ${ }^{53}$ Embora a Bahia não detivesse mais o pioneirismo ou a dianteira do setor têxtil em 1908 , tendo portanto de se haver com o crescimento de pernambucanos, mineiros, paulistas, fluminenses e cariocas, a mostra da Companhia Empório Industrial do Norte (firma sita em Salvador) não deixou de impor-se aos olhos de Marie Wright. Ela anotou que seus quase 2 mil funcionários (o que atesta o tamanho da fábrica) "viviam numa Vila Operária, uma cidade em si mesma, governada e protegida pela companhia, e fornida com escolas gratuitas, igrejas". Para ela, afora os números saudáveis da produção, funcionários e empregador passavam bem igual. ${ }^{54} \mathrm{O}$ patrão Luís Tarquínio - caixeiro pobre self-made-man como o visconde de Mauá - era de fato um empreendedor bem-sucedido; homem ligado ao desenvolvimento capitalista do país. Outro nome vinculado à ascensão social pela iniciativa privada é o do lusitano Bernardo Martins Catharino, que chegou em Salvador em 1875 - "de encomenda" - para o serviço de caixeiro e findou a vida como comendador e proprietário de outra firma têxtil de porte.

Bem-estar e progresso marcavam o pavilhão da Bahia, único em "estilo e ornamentação". ${ }^{55}$ Embora projetado pelo mesmo arquiteto do de Minas, o palacete, não apenas por causa de sua inspiração na Renascença do século XVI, exalava luxo. Exuberante, denotava preferência pela superficialidade da forma à substância do rigor. ${ }^{56}$ No piso térreo, a amostragem "de

52 WRIGHT, Marie Robinson. The Brazilian National Exposition of 1908, p.14 e 38

53 WRIGHT, Marie Robinson. The Brazilian National Exposition of 1908, p.82. Este dado de Wright foi depois confirmado por viajantes mais gabaritados no assunto. PEARSE, Arno S. Brazilian cotton. Being the report of the journey of the International cotton mission through the cotton states of São Paulo, Minas Gerais, Bahia, Alagoas, Sergipe, Pernambuco, Paraíba, Rio Grande do Norte. Manchester: Taylor, Garnett, Evans \& co., 1922.

54 WRIGHT, Marie Robinson. The Brazilian National Exposition of 1908, p.90.

55 WRIGHT, Marie Robinson. The Brazilian National Exposition of 1908, p.136

56 Sobre o ecletismo em voga na Exposição e ressaltado no edifício baiano, ver: SÁ, Marcos Moraes de. A Mansão Figner: o ecletismo e a casa burguesa no início do século XX. Rio de Janeiro, Senac, 2002, p.32. 
mais de duas mil espécimes de madeiras" fazia ver que a Bahia tinha seu lugar em meio aos outros estados que também privilegiaram a visibilidade de suas árvores majestosas e nobres, de lenho secular. Contudo, dispor de história era não menos importante. Com representações sobre eventos e personagens de seu passado, a cargo (dentre outros) de Vítor Meirelles e Rodolfo Bernardelli, a Bahia era exaltada tanto por sua beleza quanto por seu peso em datas como 1808 e 1822. À noite, o lugar ficava "indescritivelmente lindo". Tanto por causa do jardim quanto porque, com fornecimento "abundante" de energia elétrica, o prédio era "inundado de luz" - um dos maiores símbolos do progresso de então. ${ }^{57} \mathrm{Na}$ sua inauguração, foram distribuídos 50 mil postais, retratos de homens célebres, memórias e mapas. ${ }^{58}$

Herdeiros da riqueza e da opulência festiva de seus antecessores, apesar de as fortunas já não serem mais como dantes, os baianos de 1908 reconvertiam os dividendos da "supervalorização de origem ou situação urbana ou metropolitana". Segundo o pernambucano Freyre, "era como se fosse Salvador a única região civilizada, urbana, polida, do Brasil; e o mais, mato rústico". Logo, "ser baiano era ignorar a arte máscula da cavalaria. Era ser excessivamente civilizado: quase efeminado". Mas um baiano destes não ficava a pé: costumava "viajar de palanquim, de rede, de cadeira, aos ombros dos escravos". ${ }^{59}$ Nada comparável com as marchas das tropas dos gaúchos - de gado e de guerra - a cargo de bravos cavaleiros. (E assim podemos entender parte da insistência de Pinheiro Machado em fustigar a representação política gozada pela Bahia. ${ }^{60}$ Era como se a Bahia, com sua aristocracia, já fizesse parte de um círculo europeu sofisticado e seleto. Passados cem anos desde 1808, tratava-se de transitar em rodas animadas por alguma novidade francesa. E quem se instruíra em Coimbra bem estava para ser parisiense.

\section{Bota-abaixo Salvador}

Esses homens da colônia baiana de 1908, quando voltavam para Salvador, não sentiam afeto filial apenas. Rejeitavam a cidade também. Em 1912, ao assumir a administração estadual, era a remodelação de Salvador uma medida que mais magnetizava o agora governador (e ex-ministro da Viação e Obras Públicas) J. J. Seabra. Evidência de que a colônia baiana

57 WRIGHT, Marie Robinson. The Brazilian National Exposition of 1908, p.138, 141.

58 BORGES, Maria E. L. A Exposição Nacional de 1908 e a produção da identidade nacional brasileira. Anais do Museu Histórico Nacional, v.40, p.88, 2008.

59 FREYRE, Gilberto. Sobrados e mocambos. Rio de Janeiro: Editora Nacional, 1936, p.369. Sobre a relação dos soteropolitanos com a opulência, ver: MATTOSO, Kátia, Cultura e opulência na Bahia do século XIX. In: ALENCASTRO, Luiz F. de (org.). História da vida privada no Brasil, v.2. São Paulo: Companhia das Letras, 1997, p.143-179.

60 Pinheiro Machado foi uma ameaça aos interesses das elites políticas baianas em várias ocasiões. Ele contestava, por exemplo, o tamanho da bancada da Bahia, maior do que a do Rio Grande do Sul. Ver: VISCARDI, Cláudia. O teatro das oligarquias, p.86, 97. 
repatriava seus filhos, o regresso de Seabra como governador (aliado do presidente Hermes da Fonseca) manteve estreitas as relações entre ambos, ainda que no Rio tenha permanecido residente - e na oposição - o candidato a presidente derrotado em 1910, Rui Barbosa. Segundo um livro publicado em 1913 com apoio da Presidência da República - Impressões do Brasil -, "o aspecto" que Salvador oferecia, a quem dela se aproximasse "pelo lado do mar", era "encantador". Todavia, no desembarque, o enlace se desfazia e a sensação passava a não ser "das mais favoráveis"... O motivo: os antigos casarões, "grandes, pesados e de vários pavimentos", testemunhos da remota arquitetura lusa. As ruas eram "tortuosas, estreitas e pouco cuidadas"; as construções se aglomeravam desordenadas entre o mar e a montanha. Apesar do silêncio das fontes sobre a população, havia muitas restrições aos trabalhadores negros de rua, homens ou mulheres. Ao anunciar que "estas condições estão (...) prestes a se transformar", o livro promete triunfante: "a velha Bahia colonial vai desaparecer". ${ }^{61}$ Muito dessa Bahia foi destruída por mais de uma reforma urbanística.

O bota-abaixo urbanístico de Seabra foi antecedido por outro, um covarde canhoneio dirigido contra o centro histórico, e que abalou a cidade e sua população. Quando Seabra foi convidado, em 1910, por Hermes para o Ministério da Viação (que era uma pasta das mais queridas pelos lideranças partidárias por causa de seu orçamento, muitas vezes redirecionado para obras rendosas do ponto de vista político), tudo indicava que este seu prestígio avançaria inabalável no pleito estadual. Porém, como explica Luiz Henrique Dias Tavares, no instante em que sua candidatura ao governo se definiu, facções da situação baiana se moveram a fim de "adiar, ao máximo, o dia da eleição", acendendo o litígio. Como desfecho, no dia 10 de janeiro de 1912, iniciou-se o bombardeio da cidade de Salvador a partir de fortes da VII Região Militar (obediente ao comando do presidente Hermes da Fonseca). Um balaço atingiu a "velha Casa dos Governadores, um bem histórico, com mais de trezentos anos de existência". Chamas arderam na "centenária Biblioteca Pública da Bahia", o que ameaçou, danificou ou destruiu 30 mil volumes, "entre os quais obras raras". Outros "tiros alcançaram o Teatro São João e sobrados da rua Chile". ${ }^{62}$ Sobranceiros diante dos protestos repercutidos no Catete, Hermes e Seabra conservaram-se impassíveis. No mesmo ano de sua eleição e posse, 1912, Seabra deixou a pasta ministerial apenas para assumir o governo, visto que a lei não prescrevia a desincompatibilização. E o bota-abaixo da campanha seria continuado pelo bota-abaixo do exercício do mandato. Ambos foram conduzidos para favorecer Seabra, que a partir daí dominou por 12 anos.

61 LLOYD, Reginald. Impressões do Brasil no Século Vinte, p.880.

62 TAVARES, Luís Henrique Dias. História da Bahia, p.324 e 325; SARMENTO, Sílvia Noronha. A raposa e a águia, p.87 e ss. 
De um jeito ou de outro, não só Salvador iria seguir o mesmo caminho do Rio - bota-abaixo seguido de remodelação urbanística excludente como também a Bahia ombreava aquilo que chamava-se de progresso, fato intuído pela geógrafa Marie Wright, que reparou na situação de disponibilidade com que os recursos naturais foram exibidos pela Exposição de 1908. Em 1913, avaliava-se que mais de metade do território era "coberta de florestas virgens" - contendo "magníficas madeiras" -, o que levantaria "grande valor" para quem delas tivesse se apoderado. O bota-abaixo agora era de árvores.

Quem parecia imune das obrigações de dar lugar ao assim chamado progresso era açucarocracia. "As terras da Bahia poderiam produzir o açúcar necessário às necessidades de toda a Europa, se fossem devidamente cultivadas por processos racionais e aperfeiçoados", cogita Impressões do Brasil. Porém, haja vista que o plantio da cana não carecia de renovação enquanto o solo de massapê lhe garantisse a fertilidade, pouco se dera em termos de reestruturação produtiva. Em lugar "onde o estrume não chega e a charrua é raramente conhecida", a roça de cana não excedia os mesmos 30 mil hectares "já cultivados no tempo da escravidão", terminada cerca de 25 anos antes. ${ }^{63}$

\section{Açucarocracia}

Em 1922, Miguel Calmon - poucos antes da morte de Rui Barbosa em 1923, de quem buscou herdar a influência e o legado - foi feito ministro da Agricultura, Indústria e Comércio pelo presidente Bernardes. De valia para a oposição baiana ao seabrismo, sua volta ao Catete buscou agilizar a reestruturação agrícola. Atrás de Cuba, Índia e Java, a produção nacional açucareira era a quarta no plano global. No plano interno, Pernambuco e Alagoas posicionavam-se à frente da Bahia. No centro-sul, eram vanguardeiros os números de São Paulo, Minas e do norte fluminense. Há nesse retardamento algo de peculiar no ethos dos senhores de engenho do Recôncavo, no que se refere à sua desambição em industrializar o fabrico do açúcar. Porém, os fatos de serem, por um lado, antimodernos em suas propriedades e de, por outro lado, não terem se recuperado da depressão em que mergulharam com o fim da escravatura não implicam no seu ocaso ininterrupto e absoluto. Além de sua prole instruída (na qual constam Pedro Calmon, Clemente Mariani, Luiz Viana Fo e Wanderley de A. Pinho), o seu conservadorismo não é sinônimo apenas de atraso ou fraqueza. Antes, foi esteio para conferir durabilidade histórica ao racismo, ao elitismo, a tradições católicas e familiares, patriarcais e anticomunistas. Neste caso, era

63 LLOYD, Reginald. Impressões do Brasil no Século Vinte, p.877. 
como o duro miolo do escuro lenho do jacarandá-da-bahia, matéria que cupim não rói. Ou como resumiu Pedro Calmon em prefácio a livro sobre o engenho central do Bom Jardim: em seu "massapê dormiam as raízes da nacionalidade". ${ }^{64}$ A Bahia em posse desses senhores perdurava seus sobrenomes, estendia suas redes, patrimônio, igrejas e atividades econômicas, como por exemplo o setor bancário. ${ }^{65}$

Ao se haver com a resistência dos conterrâneos plantadores em mudarem de hábitos, Miguel Calmon buscou ampliar horizontes para além de seus costumes. Forneceu ajuda governamental, acolheu demandas para enfrentar a desvalorização do produto, apoiava planos de reestruturação produtiva, visando a produtividade em escala industrial, considerando necessário ir ao encontro do padrão de qualidade do mercado consumidor estrangeiro. Encorajou, de forma pioneira, planos de fabrico de álcool para fins industriais. ${ }^{66}$ Todavia, a prática senhorial era vivaz quando percebia ofertas de auxílio e proteção, mas denotava desinteresse ante os pleitos de iniciativa e ousadia. O fato remete à espera da açucarocracia baiana "até a véspera" por alguma medida indenizatória da Coroa em reparo ao fim da escravatura, o que reforça a hipótese de seu apego a uma rotina imutável. Enquanto sua congênere pernambucana, segundo Peter Eisenberg, logrou lidar com os trabalhadores em novas bases, os senhores de engenho da Bahia abalaram-se com o Treze de Maio, tibieza refletida na sua incapacidade em alavancar a industrialização do açúcar. ${ }^{67} \mathrm{Em}$ poucas palavras - e usando termos de época - os senhores se viram alienados com a "desorganização do trabalho" (a liberdade do Treze de Maio) e não lidaram bem com o "reaparelhamento econômico" (a transformação do engenho em usina).

"Difícil imaginar um trabalhador manual que envergasse gravata tão bem enlaçada", observou com agudez Regina Abreu a respeito da aquarela em que o Ministro Calmon aparece a empunhar uma charrua. Além da pose com o fito propagandístico de emular seus pares para a lida, afora também o desejo de fortalecer a liderança de Miguel, a imagem faz recordar o dado segundo o qual a cacauicultura, sem a devida representação, foi onerada com a paga de subsídios às dores do açúcar. ${ }^{68}$ Logo, a açucarocracia não

64 PANG, Eul-Soo. Engenho Central do Bom Jardim na economia baiana: alguns aspectos de sua História, 1875-1891. Rio de Janeiro: Arquivo Nacional, 1979, p.15.

65 GUIMARÃES, Antônio S. Estrutura e formação das classes sociais na Bahia. Novos Estudos Cebrap, Salvador n.18, p. 1-29, 1987.

66 SCHURZ, W. L., The Brazilian sugar industry, p.369-374

67 Açucarocracia é "termo da época consagrado por Evaldo Cabral de Melo, no livro O norte agrário e o Império para designar as relações entre os grandes proprietários da lavoura açucareira com o governo provincial e imperial, durante o Segundo Reinado". FARIA, Sheila de Castro. Açucarocracia. In: VAINFAS, Ronaldo (org.). Dicionário do Brasil Imperial. Rio de Janeiro: Objetiva, 2002, p.24. Sobre a espera dos senhores de engenho pela indenização referente à abolição da escravatura, ver: BARICKMAN, B. J. Até a Véspera. Afro-Ásia, n.21-22, p. 177-237, 19981999. Sobre a lavoura do açúcar em Pernambuco, ver: EISENBERG, Peter. Modernização sem Mudança: a indústria açucareira em Pernambuco 1840-1910. Rio de Janeiro: Paz e Terra, 1977.

68 ABREU, Regina. A fabricação do imortal, p.127. 
carecia mesmo de fazer força: podia vestir-se com elegância mesmo na hora de empunhar a suarenta charrua, na sua réplica à convocatória de Miguel para o trabalho. Em acréscimo, a imagem paradoxal de um senhor da classe dominante e uma charrua como uma coisa harmônica nos induz a especular não apenas sobre a depressão que abateu os senhores do açúcar, mas também o abandono em que se viram após a abolição, quando trabalhadores livres não se viam mais aferrados a senhores, podendo exercer o seu arbítrio. Em outras palavras, pouco restou a alguns senhores além das boas vestes para trajar e da charrua nua do braço negro. Dentre os variados destinos que os trabalhadores tomaram, há indícios de sua migração para terras onde puderam restabelecer comunidades de pescadores, no litoral do Recôncavo Sul. ${ }^{69}$

Não é o caso, pois, de varrer para debaixo do tapete o fato de a produção açucareira baiana não ter repetido desempenhos imemoriais. ${ }^{70}$ Não só a Bahia ressentiu-se disso bem como, o que já foi dito, sua proeminência nos gabinetes imperiais não se repetiu na República. Concorriam para tal, de um lado, a falta de solidariedade entre setores econômicos nativos e, de outro, cismas políticos. Mesmo assim, a agilidade e a eficácia de suas lideranças no trânsito entre Salvador e Rio não se engancharam a reboque da economia. A Bahia foi um importante estado secundário que, em certas situações (como em 1908), valorizou o seu cacife no tabuleiro republicano. Pedro Calmon inspira a indagação quando escreveu: "nesse Brasil de ontem, amanhece (com sabedoria política e antecipação inteligente) o Brasil de hoje". ${ }^{71}$

\section{Conclusão}

Sendo este artigo iniciado pela conjuntura da segunda metade dos anos 1920, em que a política do estado da Bahia deu mostras de conseguir superar seus problemas de desentendimento e dispersão, encerramos aqui apontando para o fim da mesma década e as vésperas de um processo - a Revolução de 1930 - vivido como pesadelo pelas elites baianas. Em carta de Getúlio Vargas a João Neves (datada em 31 de agosto de 1929), o missivista se pronuncia acerca da influência de Carlos Mangabeira sobre sua terra natal (a Bahia). Getúlio não desaprovou a ida de Carlos, que residia no Rio Grande do Sul, à capital, conforme propunha o seu correspondente. Porém, não apostava na "eficácia" do encontro de Carlos com seus irmãos João e Otávio Mangabeira. Ambos, escreveu Vargas, eram "homens práticos",

69 FRAGA FILHO, Walter. Migrações, itinerários e esperanças de mobilidade social no recôncavo baiano após a Abolição. Cadernos AEL, n.26, v.14, p.93-132, 2009.

70 PINHO, Wanderley de A. A Bahia, 1808-1856. In: HOLANDA, Sérgio B. História Geral da Civilização Brasileira, tomo 2, v.2. São Paulo: Difel, 1964

71 Prefácio a PANG, Eul-Soo. Engenho Central do Bom Jardim na economia baiana, p.17. 
de "âncoras fundamente lançadas na Bahia e presas ao Catete". ${ }^{72}$ Numa sentença, mirando o assunto em 1929 (logo, de fora do poder central da República), o ex-ministro da Fazenda de Washington Luís sintetiza, sobre os Mangabeira, o que aqui quisemos provar a moda de historiadores: a existência de uma prática política de âncoras fundeadas tanto na História da Bahia quanto associadas ao Catete; intimamente. Não por acaso, foi a Otávio Mangabeira a quem os revolucionários de 1930 deram permissão de visita a Washington Luís, detido no forte de Copacabana, como parte da exígua diplomacia concedida. Aliás, fora na Bahia que as últimas esperanças do presidente, de revide e reviravolta, se apagaram, tendo sido ditadas pela correlação de forças em nível nacional. Em acréscimo, enquanto o mineiro Melo Franco não surgia como nome da Revolução para o Ministério das Relações Exteriores, houve quem cogitasse que Otávio - homem preso a Washington Luís - aceitaria ficar à frente da pasta que chefiara.

Mesmo antes de a poeira das tropas revolucionárias baixar, os Calmon e os Mangabeira pendiam para o desalinho com a Revolução de 1930, a começar pelo fato de Seabra ser dirigente da Aliança Liberal. Seabra intuía no mudancismo a chance de regresso à administração estadual, deslocando quem já lhe apeara do poder. No entanto, ele também saiu frustrado com o rumo dado aos acontecimentos pelos novos donos do poder. Não por acaso, a subida do tenentista cearense Juracy Magalhães ao comando estadual foi tratada como uma usurpação de invasores estrangeiros (o interventor Juracy e seu chefe Getúlio Vargas). Ao falecerem os mentores do calmonismo no início dos anos 1930, restou a Otávio Mangabeira o papel de condottiere. Líder da Concentração Autonomista (partido que se formou na Bahia para agrupar os descontentes com a Revolução de 1930), sob sua guarda acautelaram-se Pedro Calmon, Luiz Viana Filho e Wanderley Pinho. Como vários outros autonomistas da terra, eles sabiam do que falavam quando brandiam o seu bordão: a Bahia ainda é a Bahia. ${ }^{73}$ Ao fazê-lo, pretendiam levantar veto - patrício - contra Vargas, o déspota. Com a força de sua História. Ou com a supervalorização de sua origem. Parafraseando o pintor pernambucano Cícero Dias, eles viram o mundo e ele começava em Salvador e no Recôncavo. Vale dizer, na Bahia. Tudo o mais era mato rústico.

72 CPDOC. Arquivo Getúlio Vargas, Carta, c 1929.08.31/4.

73 Sobre os autonomistas baianos, ver: PRIMO, Jacira. Tempos vermelhos: a Aliança Nacional Libertadora e a política brasileira entre 1934 e 1937. Salvador: UFBa, 2010 (História, Dissertação de mestrado), 2006, p.14 e ss. 